
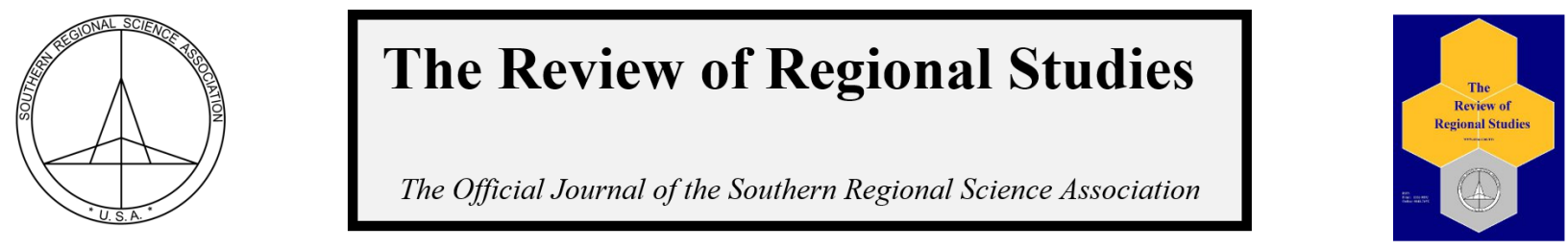

\title{
Economic Value of Visitation to Free-Flowing and Impounded Portions of the Ocklawaha River in Florida: Implications for Management of River Flow*
}

\author{
Xiang Bi, Tatiana Borisova, and Alan W. Hodges \\ Food and Resource Economics Department, University of Florida, USA
}

\begin{abstract}
The debate to restore the natural flow of Florida's Ocklawaha River or keep the impoundment (reservoir) has been ongoing since the construction of a dam as part of an abandoned cross Florida barge canal project in 1968. This study contributes to economic studies assessing trade-offs of dam removal by estimating the economic benefits and regional economic contribution of recreation at the reservoir and the upstream free-flowing river. We find that the river-based recreation generates greater benefits and contributions than the reservoir. The trade-off between restoring the river ecosystem and loss in economic value for reservoirrelated recreation can potentially be mitigated. Policy implications of the findings are discussed.
\end{abstract} Keywords: economic impact, economic expenditure, travel cost, recreation demand, avidity bias JEL Codes: R15, Q51

\section{INTRODUCTION}

River flow management through dam infrastructure plays an important role in the economy of different regions in the United States and the world, delivering hydropower, supplying irrigation and drinking water, and providing recreational opportunities and navigation (Brown

\footnotetext{
*Funding for this project was provided by the following organizations: Silver Springs Alliance, Florida Defenders of the Environment, Putnam County Environmental Council, Suwannee-St. Johns Sierra Club, Marion County Soil and Water Conservation District, St. Johns Riverkeeper, Sierra Club Foundation, and Felburn Foundation. We appreciate vehicle counter data for locations in the study area shared by the Office of Greenways and Trails (Florida Department of Environmental Protection) and Marion County Parks and Recreation. The Florida Survey Research Center at the University of Florida helped design the visitor interview questionnaire, and conducted the survey interviews with visitors. We thank Dr. Stephen Holland. Finally, research assistance by Qianyan Wu is greatly appreciated. Xiang Bi is an Assistant Professor in the Food and Resource Economics Department at the University of Florida, Gainsville. Tatiana Borisova is an Associate Professor and Extension Specialist in the Food and Resource Economics Department at the University of Florida, Gainsville. Alan W. Hodges is an Extension Specialist Emeritus in the Food and Resource Economics Department at the University of Florida, Gainsville. Corresponding Author: X. Bi, E-mail: xiangbi@ufl.edu
} 
et al., 2009; Tullos et al., 2009). In the U.S., the number of dams is estimated at 2.0 to 2.5 million, with the majority constructed for the purposes of recreation (31.9 percent), flood control (17.1 percent), fire protection (12.9 percent), irrigation (9.3 percent), or water supply (7.2 percent) (U.S. Army Corps of Engineers, 2016). Despite their important role in shaping landscapes and delivering economic and societal benefits, an estimated 75 to 90 percent of dams no longer serve their functional purposes (U.S. Army Corps of Engineers, 2016; U.S. Environmental Protection Agency, 2016). Moreover, many of the dams are reaching or exceeding their 50-year economic design life, requiring investments for renovation or demolition (U.S. Army Corps of Engineers, 2016; U.S. Environmental Protection Agency, 2016; Ho et al., 2017). In its 2017 assessment of U.S. infrastructure, the American Society of Civil Engineers assigned grade D to the dam infrastructure, with an estimated investment to repair aging high-hazard potential dams of nearly $\$ 45$ billion (American Society of Civil Engineers, 2017).

In recent years, recognition of the impact of dams on environmental functions of rivers has increased (Shuman, 1995; Graf, 1999; Null et al., 2014). Upstream and downstream, dams affect terrestrial and aquatic ecosystems, reduce floodplain productivity, and alter channel development. Inundation results in sedimentation, greenhouse gas emission, and nutrient releases. River fragmentation and flow blockages may hinder the migration of organisms, harm populations of some species, and prevent species re-distribution and adaptation (World Commission on Dams, 2000; Nilsson et al., 2005; U.S. Environmental Protection Agency, 2016).

Given the aging dam infrastructure and societal value of ecosystem services provided by free-flowing rivers, public interest in dam removal is increasing (Stanley and Doyle, 2003; ICF Consulting, 2005; Smith, 2006; Bellmore et al., 2016). As of 2015, more than 1,300 dams have been removed in the U.S. (Gilman, 2016), with the majority (865) removed in the last 20 years, indicating an accelerated rate of dam removal (Nijhuis, 2015).

There is a need for a systematic assessment of the benefits and costs associated with impounded and free-flowing rivers to better guide policy decisions in evaluating the future of dam infrastructure. Such assessment should comprehensively account for both the benefits and costs by valuing goods and services and ascertaining the non-market character of many of these goods and services. Additionally, the assessment should evaluate both the positive and negative impacts on income and employment in various economic sectors and the distributional consequences and fairness of the distribution (Whitelaw and MacMullan, 2002; Smith, 2006; Kareiva, 2012; Ho et al., 2017).

Despite the importance of the topic, the number of economic studies assessing tradeoffs associated with dam construction or removal is limited (Ho et al., 2017). An internet search returned only thirteen economic studies published in peer-reviewed journals that focused on evaluating the impacts of dam construction, management, or removal in the U.S. on the ecosystem services provided by the streams, such as recreation or wildlife habitat (summarized in the on-line Appendix Table A.1). ${ }^{1}$ Three out of the thirteen studies examined the effects of dam removal on the amenity value for nearby residential properties using hedonic property value methods (Lewis et al., 2008; Provencher et al., 2008; Bohlen and

\footnotetext{
${ }^{1}$ The online Appendix can be found at DOI: 10.13140/RG.2.2.14053.55526.
}

(C) Southern Regional Science Association 2019. 
Lewis, 2009). Two studies assessed the total economic value of free-flowing rivers compared with rivers impounded by dams, including the bequest value of preserving the resource for future generations and the existence value of providing a habitat for fish and wildlife (Loomis, 1996, 2002). One study used an economic-engineering optimization model to evaluate tradeoffs between the hydropower generation and water supply on the one hand and the benefits of river restoration on the other (Null et al., 2014).

The majority of economic studies on dam construction, management, and removal (7 out of 13) examined the impacts on tourism and recreation (i.e., cultural ecosystem services provided by streams) using economic impact analysis, travel cost method, or contingent valuation method. They generally concluded that free-flowing rivers provide greater recreational benefits than impounded rivers (Loomis, 2002; McKean et al., 2005, 2010, 2012; Kotchen et al., 2006; Robbins and Lewis, 2008). Loomis (2002) estimated the recreation benefits for a restored Lower Snake River (Idaho) using the travel cost method based on respondents' intent to travel after restoration and found that the recreational benefits are $\$ 160$ per person per day and $\$ 192$ to $\$ 310$ million per year (all currency is USD). This estimate far exceeded the benefits of the existing reservoir recreation at the Lower Snake River dams (\$31.6 million per year). McKean et al. (2010) also focused on the Snake River and considered recreational fishing. The study estimated that the average consumer surplus from fishing on the four reservoirs on the impounded section of the Lower Snake River (Idaho) was $\$ 30.06$ per person per trip, while the consumer surplus from fishing on the un-impounded river section was $\$ 71.84$. After accounting for the potentially lower visitation rate of the un-impounded section, fishing benefits of dam breaching were estimated at $\$ 2.52$ to $\$ 3.87$ million per year.

Kotchen et al. (2006) analyzed the economic consequences of the new management regime for two hydropower dams on the Manistee River (Michigan). The new regime mimics the natural flow of the river to improve fish habitat in the river and the Great Lakes compared with the old flow management regime aimed at meeting peak electricity demand. The new regime expanded the population of Chinook salmon in the Manistee River and Lake Michigan, increasing the catch rate for recreational fishing. Using the travel cost method, they estimated that the increase in catch rate translated into a $\$ 0.3$ to $\$ 1.1$ million per year increase in Michigan resident anglers' consumer surplus. Finally, Robbins and Lewis (2008) used economic impact analysis to examine the benefits of restored recreational fishing after removing Edwards Dam on the Lower Kennebec River (Maine). The total economic impact was estimated at $\$ 65.2$ million per year. While not directly comparable due to differences in methodology, this impact is significantly greater than the impact estimated before dam removal (\$21.9 million per year).

In terms of geographic coverage, six of the studies focused on rivers in the Pacific Northwest region of Washington and Idaho (Loomis et al., 1986, 2000; Loomis, 1996, 2002; McKean et al., 2005, 2010, 2012), two studies examined the Great Lakes region of Michigan and Wisconsin (Kotchen et al., 2006; Provencher et al., 2008), three studies examined cases in the New England region (Lewis et al., 2008; Robbins and Lewis, 2008; Bohlen and Lewis, 2009), and one study discussed dam removal trade-offs in California (Null et al., 2014). Based on a review of existing literature, this study is the first to examine dam construction, management, or removal in the southern U.S.

The lack of studies on the economic and ecological consequences of dam management 
highlights the need for additional research in this area (ICF Consulting, 2005; Bellmore et al., 2016). Bellmore et al. (2016) estimated that only 9 percent of all U.S. dam removal projects had been evaluated from physical, biological, or water quality perspectives. Kibler et al. (2011) indicated that the economic outcomes of only 5 percent of dam removal projects have been published in the scientific literature. In Florida alone, there are 1,203 large or potentially hazardous dams, and 35 percent of them were constructed 50 or more years ago (U.S. Army Corps of Engineers, 2016), potentially requiring an investment decision to reinforce or demolish the dams.

This paper contributes to the literature on estimating the economic impact of dam management and removal by focusing on a long-standing controversy in Florida. Unlike other published studies where a dam and the related impoundment creates an impediment for recreation by blocking upstream fish migration and related fishing opportunities, recreation opportunities are available on both the impounded and free-flowing stretches of the Ocklawaha River. The Ocklawaha River provides a unique opportunity to examine the benefits of dam maintenance or dam removal scenarios. The dam built on the Ocklawaha River has never been used for hydropower generation, navigation, water storage purposes, or amenities for waterfront properties; rather, recreation is the primary use of the river and the reservoir. The recreational opportunities and experiences include largemouth bass fishing in the impounded portion and canoeing, kayaking, sightseeing, and wildlife viewing opportunities along the river's free-flowing stretches. As a result, recreationists' interests are divided, with passionate support expressed by recreationists both for and against dam removal, highlighting the importance of evaluating the distributional impacts from dam management or removal. Moreover, analyzing this site allows us to construct a counterfactual for the river restoration scenario. Reservoir management includes periodical drawdowns to control aquatic plant and fish populations. This allows us to compare recreation along the freeflowing and impounded sections of the river, as well as recreation during the normal management regime of the reservoir with the reservoir drawdown, when the river is comparable to the restored conditions.

This study estimates the value that visitors derive from recreation and the regional economic contribution of recreation to explore the economic arguments related to the recreational use of the impounded versus natural stretches of the river, as well as to examine the potential economic implications of dam removal. We use a combination of site visitation data collected by government agencies and intercept visitor survey responses at reservoir and river access sites under drawdown and normal water management as primary data sources. By examining differences in the survey responses among visitors engaging in different types of recreational activities at different locations, and having different income status and home locations, we are able to explore the distributional issues associated with preservation and removal of the dam.

\section{STUDY AREA}

The controversy surrounding water resource management and economic development in the Ocklawaha River Basin began long ago, but continues to influence current decisions. The idea of constructing a cross-Florida canal to allow ship passage from the Atlantic Ocean to 
the Gulf of Mexico started in the early 1800s, and was formalized in the 1930s when plans were developed to dredge a 100-mile long channel across the state to connect the St. Johns, Ocklawaha, and Withlacoochee Rivers (Appendix Figure A.1). The canal construction began in 1935 and after a temporary suspension, restarted in 1964. In response to fierce opposition by a coalition of various environmental groups, construction was stopped permanently by Presidential order in 1971 (Noll and Tegeder, 2015).

Among the primary concerns about the barge canal were the potential impacts of the project on Florida's natural resources. The project was de-authorized in 1991. Later, in 1998, the 110-mile corridor of land originally set aside for the canal construction officially became the Marjorie Harris Carr Cross Florida Greenway State Recreation and Conservation Area to honor her effort to stop the cross-Florida canal construction through the Florida Defenders of the Environment (Florida Department of Environmental Protection, 2001; Noll and Tegeder, 2015). The Cross Florida Greenway provides ample recreation opportunities, at an estimated annual economic impact of $\$ 74.3$ million (Governor Rick Scott, 2016).

Prior to 1971, part of the work for the canal construction was completed, including the Buckman Canal and Lock (connecting the Ocklawaha and St. Johns Rivers), Eureka Dam, and Rodman Dam, later renamed as the George Kirkpatrick Dam. The Eureka Dam's lock structure remains in place although the dam is land-locked. The Kirkpatrick Dam is an earth-filled structure measuring 22 feet high and 6,800 feet long, with a concrete spillway and four gates that impound the Ocklawaha River to form the Rodman Reservoir (Shuman, 1995). Over 20 springs and approximately 7,000 acres of seasonally flooded forest wetlands were permanently flooded (Lewis personal communications).

The impoundment has resulted in fragmentation of important north-south wildlife corridors traversing the river, altering this area's wildlife habitat. Kirkpatrick Dam prevents or complicates the upstream passage of fish and aquatic animals, such as channel catfish, striped bass, and manatees, with some species classified as threatened or endangered. Fish diversity has become limited in the upstream portions, particularly at Silver Springs (Lewis, 2015). Changes in the Silver Springs ecosystem, caused by the reduction of abundance and diversity of species, along with the impacts of urban development in the basin, has led to changes in the clarity of the Springs water, impacting snorkeling, swimming, and glass-bottom-boatride experiences of visitors. Kirkpatrick Dam also has had a negative impact the movement of sediment and flow to downstream portions of the Ocklawaha River and St. Johns River (Shuman, 1995; Lewis, 2015).

In the years since the construction of the Kirkpatrick Dam, the Rodman Reservoir has developed its own ecosystem, providing habitat for multiple species of fish, birds, and other wildlife. Fishing and motorized/non-motorized boating opportunities are available at Rodman Reservoir, which has become a preferred location for bass fishing tournaments and other reservoir-based recreation in Florida (Florida Fish and Wildlife Conservation Commission, 2018).

However, the reservoir ecosystem depends on heavy management, with drawdowns conducted every three to four years during the winter months to control aquatic vegetation and to enhance wildlife habitat. During drawdown events, the surface level of the reservoir is reduced from approximately 18 feet to 11 feet for about 3 months. Reservoir drawdowns expose submerged aquatic vegetation and bottom sediments. Drawdowns are an important 
tool to reduce floating aquatic weeds and hydrilla coverage, as well as increase native vegetation spread while reducing the use of herbicides for weed control. Drawdowns also improve game fish conditions in the following years (Florida Department of Environmental Protection, 2015). Periodic drawdowns provide a glimpse into the system conditions possible in the case of river restoration, with multiple springs otherwise submerged under the reservoir becoming visible, increasing river water transparency and attracting canoe and kayak recreationists. The drawdowns expose tree stumps otherwise covered by the reservoir water level, complicating fishing on the reservoir during the drawdown months. Finally, the drawdowns allow the floodplain to dry, possibly helping flooded trees survive, though under poor conditions.

In 1993, in response to repeated calls for river restoration, the Florida Legislature provided funding to examine four management alternatives: (1) full restoration to remove all structures and restore the river hydrology and floodplain; (2) partial restoration with limited removal of structures and restoration of the river hydrology and floodplain function; (3) partial retention to reduce the size of the impoundment and restore a portion of the river; and (4) full retention of the reservoir and active management of fish and wildlife (Florida Department of Environmental Protection, 1995; Shuman, 1995; U.S. Department of Agriculture Forest Service, 2001). After examining the potential consequences of each management alternative, the Florida Department of Environmental Protection (FDEP) and several other state and federal agencies supported the partial restoration alternative with only a small portion of the dam removed. This option, which would restore the connection of the Ocklawaha River channel above and below the dam, while maintaining public access to the boat ramp and recreation areas at the dam, was never implemented due to lack of general support and funding (U.S. Department of Agriculture Forest Service, 2001).

Unlike the debate on dam removal in other states, for Florida's Kirkpatrick Dam impounding the Ocklawaha River, the arguments related to environmental protection and recreational use come from both the dam supporters and their opponents. The dam supporters are interested in bass fishing in the impoundment and emphasize the importance of the large lake-type ecosystem developed over the past 50 years since the dam's construction. The opponents argue for improving migratory fish passage and upstream river environmental conditions by removing the dam, and the importance of recreational experiences along the free-flowing river.

Meanwhile, the demographic makeup and recreation preferences have changed in the region. The Ocklawaha River has seen increasing use of nature-based recreation other than fishing. The economic studies evaluating restoration alternatives in the 1990s are becoming outdated given these changes. For example, the potential to increase river-based and springsbased recreation with restoration as submerged springs re-appear and the clarity of the Ocklawaha and Silver Rivers improve during the periodic drawdowns was not examined in the previous study. Due to the flaws in the previous study, additional studies examining visitation and public preferences for Ocklawaha River management could help find acceptable solutions to the long-standing controversy.

(C)Southern Regional Science Association 2019. 


\section{DATA}

\subsection{Primary Data Collection}

To allow for the analysis of recreational visitors' opinions regarding river management and dam removal and to estimate visitors' recreational expenditures and benefits for recreation, randomly selected visitors along the free-flowing and impounded sections of the Ocklawaha River participated in a personal-interview survey during February and March of 2016 and 2017. The survey elicited information about visitors on (a) activities at the site; (b) knowledge and opinions about alternative management strategies; (c) expenditures for the visit/trip; (d) frequency of visiting location; (e) potential change in visitation if the Kirkpatrick Dam were breached (only elicited in 2017); and (e) demographic characteristics.

The five interview locations chosen, Kirkpatrick Dam and Recreational Areas, Kenwood Landing, Eureka Dam (West), Ray Wayside Park, and Silver Springs State Park canoe and kayak launch, represent all three types of amenities available along the Ocklawaha River (on-line Appendix Figure A2). These locations were chosen based on discussions with local environmental and recreation groups as the most popular locations for reservoir (Kirkpatrick and Kenwood), river (Eureka and Ray), and springs (Silver Springs) visitors.

In order to have a balanced representation of all recreation activities under drawdown and normal management of the reservoir, approximately equal numbers of surveys were conducted for each interview location site and equal numbers of responses were collected during the drawdown period in 2016 and normal management period in 2017. Based on discussions with local environmental and recreation groups, in addition to experience and observation from survey interviewers, the majority of the recreation activities took place during weekends. Weekdays and weekends were randomly selected for interviews, with twothirds of the responses collected during weekends, and one-third collected during weekdays.

The total number of interview responses was 681 (Table 1). The majority of the respondents were male (67.3 percent). The median age of all respondents was 55 years old (with an age range from 18 to 93). In contrast, the median age of the Florida population is 41 year old. Many of the respondents were employed full-time (44.5 percent) or retired (33.5 percent). Household income distribution was as follows: below $\$ 35,000$ (20.9 percent); $\$ 35,000$ to $\$ 49,999$ (15.0 percent); $\$ 50,000$ to $\$ 69,999$ (15.9 percent); $\$ 70,000$ to $\$ 89,999$ (11.8 percent), and $\$ 90,000$ or more (15.4 percent), with 43.3 percent of the sample reporting household income above $\$ 50,000$. The median household income in Florida is $\$ 47,212$, and 49.2 percent of the Florida population has household income above 50,000. Almost one-half of the respondents (46.3 percent) had at least a college degree, compared to 27.9 percent of the Florida population.

In sum, the sample differs from the Florida population in terms of median age and percent with a college or higher degree. Note that this difference reflects the general makeup of recreational visitors to the area. For example, according to U.S. Fish and Wildlife Service (U.S. Fish and Wildlife Service, 2016), anglers and wildlife watchers tend to be older, while Dolnicar et al. (2010) report that people who participate in sustainable tourism and ecotourism tend to be more educated and have higher incomes.

(C)Southern Regional Science Association 2019. 
Table 1: Survey Respondents' Socio-Demographic Characteristics

\begin{tabular}{lcc}
\hline \hline & $\begin{array}{c}\text { Survey Sample } \\
(\mathrm{N}=681)\end{array}$ & $\begin{array}{c}\text { Florida Population } \\
\text { (US Census Bureau) }\end{array}$ \\
\hline Female & $37.8 \%$ & $51.0 \%$ \\
Age & 55 & 41 \\
$\quad$ Median age & $25.0 \%$ & $17.3 \%$ \\
$\quad$ Above 65 years old & & \\
Employment status & $44.5 \%$ & $52.7 \%$ \\
$\quad$ Employed full-time & $33.5 \%$ & N.A. \\
Retired & & \\
Household income & $20.9 \%$ & $36.0 \%$ \\
Below $\$ 35,000$ & $15.0 \%$ & $14.9 \%$ \\
$\quad \$ 35,000$ to $\$ 49,999$ & $43.3 \%$ & $49.2 \%$ \\
Above $\$ 50,000$ & $15.9 \%$ & N.A. \\
$\quad \$ 50,000$ to $\$ 69,000$ & $11.8 \%$ & N.A. \\
$\quad \$ 70,000$ to $\$ 89,999$ & $15.4 \%$ & N.A. \\
$\quad \$ 90,000$ or more & $21.2 \%$ & N.A. \\
Not sure/Refused & & \\
Highest Level of Education Completed & $5.8 \%$ & $5.2 \%$ \\
Primary school (through $9^{\text {th }}$ grade) & $30.1 \%$ & $29.2 \%$ \\
High school diploma or GED & $17.3 \%$ & $20.6 \%$ \\
Some college, no degree & $46.3 \%$ & $27.9 \%$ \\
College degree or higher & & \\
\hline \hline
\end{tabular}

Source: U.S. Census Bureau (2016)

\subsection{Secondary Data}

Many of the recreation users in Florida come from other states (Visit Florida, 2017), so we use secondary data from automated vehicle counters at recreation access points collected by the Florida Department of Environmental Protection, Office of Greenways and Trails, and Marion County Department of Parks and Recreation to estimate the percentage of Florida recreation users. A map of public recreation sites and access points on the Rodman Reservoir (Lake Ocklawaha) and lower Ocklawaha River is shown in Appendix Figure A3.

Data were obtained for 17 recreation access points (sites), which were classified depending upon whether they provided access to the natural stretches of the Ocklawaha River (8 sites) or Rodman Reservoir (9 sites). These recreation sites depend on the dam infrastructure. The assumption implicitly made in this study was that this infrastructure will largely remain even if the dam were breached to restore river flow.

The equipment for counting visitor vehicles used inductive-loop sensors placed in the roadways to measure traffic in one direction only to avoid double counting, as well as to avoid double counting vehicles with trailers. After reviewing the placement of counters, vehicle counts for four sites (Rodman Campground, Rodman Road West, Rodman Recreation 
Table 2: Estimated Total Annual Visitor Groups to the Ocklawaha River and Rodman Reservoir Recreation Sites, 2013-2017

\begin{tabular}{lcccc}
\hline \hline & $\begin{array}{c}\text { Total } \\
\text { Visitors }\end{array}$ & $\begin{array}{c}\text { Percent } \\
\text { Non-local }\end{array}$ & $\begin{array}{c}\text { Non-local } \\
\text { Visitors }\end{array}$ & $\begin{array}{c}\text { Local } \\
\text { Visitors }\end{array}$ \\
\hline Reservoir sites $^{\mathrm{a}}$ & 130,304 & 66.9 & 81,173 & 43,131 \\
River sites $^{\mathrm{b}}$ & 231,350 & 47.5 & 109,891 & 121,459 \\
Total all sites & 361,654 & & 197,065 & 164,589 \\
\hline \hline
\end{tabular}

${ }^{\mathrm{a}}$ Excluded duplicated counter sites.

${ }^{\mathrm{b}}$ Included Rodman Recreation Areas West that provide access to the natural river below Rodman Dam.

${ }^{\mathrm{c}}$ Percent non-local estimated from visitor survey. Non-local visitors are defined as traveling more than 50 miles from home zip code centroid to the recreation site.

Source: Florida Greenways and Trails and Marion County Parks and Recreation, automated traffic counts.

Area-East, and Rodman Recreation Area-West) were removed from the total vehicle counts to avoid double counting vehicles entering the Rodman area from Highway 19.

Vehicle counts during the five-year period 2013 - 2017 were taken as representative of current conditions for economic analysis. As shown in Table 2, average annual visitation for all sites during 2013 - 2017 was estimated at 361,654 groups, including 231,350 groups to Ocklawaha River sites and 130,304 groups to Rodman Reservoir sites, excluding the duplicated counts. The vehicle count data are assumed to be representative of the number of visitor groups, rather than individuals.

\section{METHODS}

\subsection{Travel Cost Method}

To compare visitors' willingness to pay for the use of free-flowing and impounded sections of the Ocklawaha River, we used the Travel Cost Method (TCM) to estimate values derived from recreational experiences. Under a single-site framework, a recreation demand function was estimated on the number of trips as a function of visitors' travel cost to the recreation site, travel cost to an alternative site, income, and demographic characteristics Haab and McConnell (2002).

Following previous literature, our estimated demand function uses the exponential function in which the expected number of trips is shown as:

$$
\lambda_{i}=\exp \left(\beta_{0}+\beta_{1} t c_{i}+\beta_{2} x_{2 i}+\beta_{3} x_{3 i}+\ldots+\beta_{k} x_{k i}\right)
$$

where $t c_{i}$ is is the travel cost variable for individual $i$.

The consumer surplus of a trip to the site can then be assessed using the results from the estimation using Equation (2) (Bockstael and Strand, 1987; Haab and McConnell, 2002). 
Consumer surplus under this income-constant recreation demand curve can be used to approximate the willingness to pay to access the recreation site, given the income effect on recreation is typically low and recreation only accounts for a small share of the household budget (Haab and McConnell, 2002). The annual consumer surplus at the household level can be obtained multiplying Equation (2) by the predicted number of trips. Because the distribution of the consumer surplus in Equation (2) is undefined, we use the parametric bootstrapping procedure by Krinsky and Robb (1986) to produce the simulated distribution of per household per trip consumer surplus based on 1000 draws from its posterior distribution to obtain the 95 percent confidence interval.

$$
\text { CS/household/trip }=-1 / \hat{\beta}_{1} \text {. }
$$

Estimating Equation (1) using on-site survey data requires correction for both endogenous stratification and truncation. For example, users of the recreation site who visit more frequently are more likely to be included in the sample than users who visit only occasionally. As a result, the sample is endogenously stratified by trip frequency. Additionally, the number of trips is a non-negative integer in the sample (as in the population), and it is truncated at one since visitors who have taken at least one trip are included in the on-site sample (Shaw, 1988; Englin and Shonkwiler, 1995). Without correction, the estimators in the recreation demand model will be biased and inconsistent. Correction on truncation and endogenous stratification can be made by adjusting the conditional distribution of trip frequency.

Shaw (1988) shows the correction for the Poisson distribution by subtracting 1 from the observed level of the dependent variable. Specifically, the density function of observing visitor $i$ making $T$ trips in the onsite sample conditional on the visitor's characteristics $x$ will be:

$$
h\left(T_{i} \mid X_{i}\right)=e^{-\lambda} \lambda^{T_{i-1}} /\left(T_{i}-1\right) !
$$

The expected number of trips will be $E\left(T_{i} \mid X\right)=\lambda_{i}+1$, and the variance will be $\operatorname{Var}\left(T_{i} \mid X\right)=\lambda_{i}$

However, this approach has the drawback of assuming that the conditional mean is equal to the variance (equi-dispersion). In the presence of over dispersion, Negative Binomial distributions can be used. Englin and Shonkwiler (1995) extend Shaw (1988) to the Negative Binomial distribution, allowing for over-dispersion of the dependent variable. They show that the density function for a Negative Binomial distribution can be written as:

$$
h\left(T_{i} \mid X_{i}\right)=\frac{T_{i} \Gamma\left(T_{i}+1 / \alpha_{i}\right) \alpha_{i}^{T_{i}} \lambda_{i}^{T_{i-1}}\left[1+\alpha_{i} \lambda_{i}\right]^{-\left(T_{i}+1 / \alpha_{i}\right)}}{\Gamma\left(T_{i}+1\right) \Gamma\left(1 / \alpha_{i}\right)}
$$

where the expected number of trips wil bee $E\left(T_{i} \mid X\right)=\lambda_{i}+1+\alpha_{i} \lambda_{i}$ and $\operatorname{Var}\left(T_{i} \mid X\right)=$ $\lambda_{i}\left(1+\alpha_{i}+\alpha_{i} \lambda_{i}+\alpha_{i}^{2} \lambda\right)$. Using the parameter $\alpha_{i}=\alpha_{0} / \lambda_{i}, E\left(T_{i} \mid X\right)=\lambda_{i}+1+\alpha_{0}$ and $\operatorname{Var}\left(T_{i} \mid X\right)=\lambda_{i}+\alpha_{0}+\alpha_{0} \lambda_{i}+\alpha_{0}^{2}$.

To select the Poisson vs. Negative Binomial distribution, one can examine the statistical significance of the over-dispersion parameter in the Negative Binomial estimates and the 
Akaike information criteria (AIC). In this study, we report the estimates based on Shaw (1988) and Englin and Shonkwiler (1995). ${ }^{2}$

To empirically estimate the TCM model, each respondent's travel cost to the study area was estimated using the monetary cost of travel and the opportunity cost of travel time. Following the practice of the existing studies, we determined the centroid of the visitor's home zip code to estimate the distance traveled to the recreation location using the Google map functions in MS Excel. The cost per mile is $\$ 0.575$ based on the standard mileage rate determined by the Internal Revenue Service and the average travel speed is assumed to be 40 miles per hour (Internal Revenue Service, 2015). The cost per mile is multiplied by the round-trip travel distance from the centroid of the respondent's home zip code to a recreation site to determine the monetary cost of the travel. The opportunity cost of the travel time is calculated by multiplying a fraction of the implicit hourly wage rate by the time spent traveling. Following the TCM literature, the implicit hourly wage rate is calculated as the household income divided by 2,080 hours, assuming a 40-hour workweek for 52 weeks a year. The fraction of this implicit wage rate is assumed to be 0.33 based on previous studies (e.g. Whitehead et al. (2000); Parsons (2003)). Furthermore, household income was a categorical response in the survey. It was converted to the midpoint of each category in calculating the travel cost variable. For respondents declining to reveal household income to the enumerators, we used their reported level of education, employment status, and age to predict the missing values, following Bin et al. (2005).

Other variables in the travel demand models included travel cost to an alternative location for similar recreation activity, respondent's household income, a dummy variable that equals 1 if the respondent is female, respondent's age, a dummy variable that equals 1 if the primary recreation activity is fishing from onshore or boat, and a dummy variable that equals 1 if the primary recreation activity is non-motorized boating (e.g., canoeing or kayaking). To calculate travel cost to an alternative site, we asked respondents to identify an alternative site for similar recreation activities if the study area they were visiting was unavailable. Similar to the calculation of the travel cost variable, we used the monetary trip cost and opportunity cost of time for estimating the travel cost to an alternative site. ${ }^{3}$

\subsection{Economic Contribution Analysis}

To assess the economic contributions to the local economy associated with recreational activities and visitor spending along free-flowing and impounded sections of the Ocklawaha River,

\footnotetext{
${ }^{2}$ All of the methods discussed so far are based on imposing the distribution assumption on the population of trip frequency. More recently, Shi and Huang (2018) showed that instead of imposing the distribution assumptions on the trip frequency, one could treat truncation and endogenous stratification separately. Given the empirical distribution of trip frequency in the on-site sample, one can use the reported trip frequency in the sample to re-weight each observation in estimating the travel cost model using truncated distributions. Following their method, our estimated coefficients of travel cost for the weighted zero-truncated Poisson and Negative Binomial models are very similar to the results using Shaw's method. We thank the anonymous reviewer for suggesting Shi and Huang (2018).

${ }^{3}$ As a robustness check, we also estimated the TCM as an incomplete demand system as in Landry et al. (2016), in which travel cost to an alternative site is excluded in the TCM since the incomplete demand system has to satisfy homogenous degree zero in all prices and income. The empirical results were qualitatively similar to the results reported in this article.
}

(c)Southern Regional Science Association 2019. 
a regional economic model was constructed using the IMPLAN software and associated 2015 database for Florida counties (IMPLAN Group, LLC, 2004). IMPLAN models are based on Input-Output analysis and Social Accounting Matrices that describe the flow of goods and services within a regional economy and are widely used for estimating regional economic impacts or contributions of various economic events, activities, policies, and programs (Miller and Blair, 2009). In this case, the model was created for the three counties of Putnam, Marion, and Alachua using the commodity trade flows gravity model specification).

Economic contributions associated with river-based or reservoir-based recreational spending were estimated using regional multipliers for each industry sector calculated by the IMPLAN model. Spending by non-local visitors was considered to be new final demand to the region, subject to all direct, indirect, and induced multiplier effects, while spending by local residents was treated as a transfer payment, subject only to the direct multiplier effects, as is common practice for economic contribution analysis of travel and tourism sectors. Each expenditure category was assigned to the appropriate IMPLAN industry sector based on North American Industry Classification System descriptions.

Economic contributions were evaluated in terms of industry output, employment labor income, and value added, representing the value of output less the cost of inputs purchased from other businesses. This measure is comparable to Gross Regional Product (GRP).

An accurate economic contribution analysis also takes into account the nature of the endogenously stratified onsite sample, as the sample mean and standard deviations of variables related to trip frequency do not represent the population mean and standard deviation of the users, referred to as avidity bias. For example, users who live nearby are more likely to frequent the site, and thus are more likely to be included in the on-site sample. As a result, the mean trip expenditure calculated from the on-site sample is likely to be underestimated. Thomson (1991) showed that corrections can be made on the sample mean and standard deviation with information obtained from the on-site sample alone, without using information from the population.

The probability of observing user $i$ who took $T_{i}$ trips in an on-site sample is $P=T_{i} / T$ where $T$ represents the total number of trips taken by the population $N$ and $T=\sum_{i=1}^{N} T_{i}$.

The population mean of a variable $Z_{i}$ can be estimated by $\hat{Z}=\frac{1}{n} \sum_{i=1}^{n} Z_{i} / P_{i}$, where $n$ denotes the sample size from the onsite sample. The size of the population $N$ can be estimated by $\hat{N}=\frac{1}{n} \sum_{i=1}^{n} 1 / P_{i}$.

The population mean of the variable $Z$ can be estimated as $\hat{Z} / \hat{N}$ and using information from the onsite sample alone, one can estimate this ratio as $\hat{Z} / \hat{N}=\frac{\sum_{1}^{n} Z_{i} / T_{i}}{\sum_{1}^{n} 1 / T_{i}}$.

The variance of $\hat{Z} / \hat{N}$ can be estimated using the information from the onsite sample, where $\mathrm{m}$ denotes the estimated population mean $\hat{Z} / \hat{N}$ and $\bar{T}$ represents the average number of the trips in the sample:

$$
\operatorname{var}\left(\frac{\hat{Z}}{\hat{N}}\right)=\frac{1}{n} *\left(m^{2}\right)\left(\frac{s_{z / t}^{2}}{m^{2}}+S_{1 / t}^{2}-2 S_{z / t} S_{1 / t} *\left(\frac{1}{m}\right)\right)
$$

where:

(C)Southern Regional Science Association 2019. 


$$
\begin{gathered}
S_{Z / t}^{2}=\frac{\bar{T}}{n-1} \sum_{i=1}^{n}\left(\frac{Z_{i}}{T_{i}}\right)^{2}-\frac{1}{n} *\left(\sum_{i-1}^{n} \frac{Z_{i}}{T_{i}}\right)^{2} \\
S_{1 / t}^{2}=\frac{\bar{T}}{n-1} \sum_{i=1}^{n}\left(\frac{1}{T_{i}}\right)^{2}-\frac{1}{n} *\left(\sum_{i-1}^{n} \frac{1}{T_{i}}\right)^{2} \\
S_{Z / t} S_{1 / t}=\frac{\bar{T}}{n-1}\left(\sum_{i=1}^{n}\left(\frac{Z_{i}}{T_{i}} * \frac{1}{T_{i}}\right)-\frac{1}{n} * \sum_{i-1}^{n} \frac{Z_{i}}{T_{i}} * \sum_{i=1}^{n} \frac{1}{T_{i}}\right)
\end{gathered}
$$

In this study, Thomson's correction for avidity bias was first applied to the mean expenditure levels and the adjusted means were used in the economic contribution analysis.

\section{RESULTS}

\subsection{Trip Characteristics during Drawdown and Normal Management Regimes}

We summarize the average trip characteristics for survey responses during the reservoir drawdown period in 2016 and the normal management period in 2017. The average trip frequency was 24.3 in 2016 and 14.4 in 2017 (Table 3). The difference between the two periods was only marginally statistically significant $(\mathrm{p}<10$ percent) using the WilcoxonMann-Whitney test.

Table 3: Visitation Characteristics during Drawdown and Normal Management Periods

\begin{tabular}{lcc}
\hline \hline & $\begin{array}{c}2016 \\
\text { (drawdown } \\
\text { Mean Characteristics }\end{array}$ & $\begin{array}{c}2017 \\
\text { ("normal" regime } \\
\mathrm{N}=251)\end{array}$ \\
\hline Trip frequency & $24.3^{*}$ & 14.4 \\
Age (years) & 52.9 & 51.4 \\
Female (\%) & 30 & 33 \\
Fishing (\%) & 50 & 52 \\
Fishing from boat (\%) & 21 & 27 \\
Fishing from shore (\%) & 29 & 26 \\
Non-motorized boating (\%) & $33^{* * *}$ & 15 \\
One-way driving distance to the site (miles) & 57.0 & 58.1 \\
One-way driving distance to an alternative site (miles) & 160.0 & 180.7 \\
Household income & $\$ 55,942$ & $\$ 57,018$ \\
Travel cost to the site (round-trip) & $\$ 86$ & $\$ 87$ \\
Travel cost to an alternative site (round-trip) & $\$ 218$ & $\$ 246$ \\
\hline \hline
\end{tabular}

Note: Wilcoxon-Mann-Whitney tests between 2016 and 2017; difference is statistically significant at probability $<10 \%$. ${ }^{* * *}$ Pearson's Chi-squared test indicated percent of respondents engaged in nonmotorized boating is statistically different between the two management regimes at $\mathrm{p}<5 \%$.

(c)Southern Regional Science Association 2019. 
Table 4: Raw and Adjusted Mean and Standard Deviations for Trip Spending by Survey Respondents

\begin{tabular}{lcccc}
\hline \hline & \multicolumn{2}{c}{ Raw } & \multicolumn{2}{c}{ Adusted } \\
Expense Category & Mean & Std. Dev. & Mean & Std. Dev \\
\hline Restaurant & 31.04 & 83.37 & 46.67 & 39.21 \\
Food and beverage & 23.43 & 61.94 & 30.69 & 24.14 \\
Lodging & 36.53 & 178.35 & 57.18 & 83.63 \\
Rental Car & 6.71 & 71.14 & 7.73 & 16.40 \\
Gas & 36.14 & 79.26 & 46.10 & 29.87 \\
Fees & 9.56 & 43.34 & 13.73 & 17.35 \\
Transportation & 5.77 & 38.88 & 11.06 & 21.04 \\
Entertainment & 3.02 & 15.03 & 5.32 & 8.21 \\
Recreation Gear & 7.68 & 32.83 & 8.05 & 10.19 \\
Shopping & 13.55 & 53.25 & 19.66 & 23.79 \\
Other Purchases & 5.00 & 20.90 & 7.22 & 11.09 \\
Total trip expenditure & 178.44 & 61.67 & 253.42 & 25.90 \\
\hline \hline N $=681$ & \multicolumn{4}{c}{} \\
\hline
\end{tabular}

Around 50 percent of the respondents were fishing from either a boat or onshore and their average one-way travel distance to the area was 57 miles. We found no statistically significant differences between other trip characteristics across the two survey periods except for the percentage of respondents engaged in non-motorized boating activities, which was 33 percent during the drawdown period versus 15 percent during the normal management period. This reduction is expected since drawdown enhances the non-motorized boating experience by exposing the river channels and springs that were previously submerged by the impoundment.

Based on this finding, we proceeded with pooling the two survey data periods together in the recreation demand and economic contribution analysis. In estimating the consumer surplus through the TCM, we included dummy variables for non-motorized boating and fishing activities to allow for shifts in the expected trip frequency.

\subsection{Trip Expenses, Correction for Avidity Bias, and Economic Impacts}

Table 4 summarizes the means and standard deviations of trip expenditures before correction for avidity bias (columns 1 and 2) and after correction (columns 3 and 4). As expected, without correction, the mean total trip expenditure and all categories of expenditures were underestimated. On average, the total trip expenditure per visitor-group per day was about $\$ 253$, 40 percent more than the total expenditure without correcting for avidity bias. The expense categories that were greatly underestimated were gas, transportation, lodging, food, and beverage.

Table 5 presents mean expenditures by local visitors and non-local visitors and by recreation sites visited. Non-local visitors were defined as those traveling more than 50 miles from 
Table 5: Expenditure Summary Adjusted for Avidity Bias by Type of Recreation Sites and Visitor Origin

\begin{tabular}{lcccc}
\hline \hline & \multicolumn{3}{c}{ Reservoir } & \multicolumn{2}{c}{ River } \\
Expenditure Type & Local & Non-local & Local & Non-local \\
\hline Restaurant & (mean & dollars per & party-visitor per day) \\
Food and beverage & 20.81 & 12.28 & 3.72 & 14.08 \\
Lodging & 11.22 & 6.47 & 6.83 & 14.73 \\
Rental Car & 14.64 & 15.31 & 0.06 & 27.24 \\
Gas & 2.32 & 2.30 & 0.01 & 2.74 \\
Fees & 17.71 & 11.14 & 10.52 & 17.21 \\
Transportation & 10.29 & 3.45 & 0.09 & 1.28 \\
Entertainment & 2.93 & 2.11 & 0.49 & 7.51 \\
Recreation Gear & 1.34 & 1.92 & 0.09 & 1.10 \\
Shopping & 4.53 & 1.72 & 2.76 & 2.15 \\
Other Purchases & 8.46 & 6.28 & 1.51 & 3.03 \\
Total tip expenditure & 3.62 & 1.93 & 0.58 & 1.72 \\
\hline \hline
\end{tabular}

Note: Non-local visitors defined as traveling more than 50 miles from home zip code centroid to recreation site. $\mathrm{N}=681$.

their home zip code centroid to a recreation site. The average trip expenditures by local visitors at reservoir sites were $\$ 97.86$ per visitor-group per day, while the expenditures by non-local visitors at reservoir sites were $\$ 64.92$. In contrast, local visitors at river sites spent just $\$ 26.67$, which is much less than local reservoir visitors. However, non-local visitors at the river sites spent $\$ 92.80$, which is similar to the spending level of local reservoir visitors.

The average expenditures per group-day reported in Table 5 were multiplied by the annual number of local and non-local visitor groups, based on the average vehicle counts during 20132017 to estimate total annual visitor spending, which were applied to the economic multipliers from the regional economic model to estimate total regional economic contributions.

Table 6 summarizes the total economic contributions of visitor spending for recreational use at the Ocklawaha River and Rodman Reservoir. The total contributions included employment of 356 full-time and part-time jobs, $\$ 16.23$ million in value added or Gross Regional Product (GRP), $\$ 10.26$ million in labor income, and $\$ 28.30$ million in industry output or business revenues (Table 6 ). The economic contributions for spending by visitors to riverbased recreational sites (201 jobs and $\$ 9.65$ million GRP) were about 30 percent more than those for visitors to reservoir sites (155 jobs, $\$ 6.68$ million GRP). One reason for this difference is that there were more recreation access points along the 35 miles of the river than the 15-mile length of the reservoir.

\subsection{Recreation Demand Model and Consumer Surplus}

Estimates on recreation demand using the Negative Binomial models correcting for endogenous stratification and truncation are reported in the first two columns of Table 7 and, for 


\begin{tabular}{lcccc}
\multicolumn{5}{c}{ Table 6: Total Economic Contributions of Recreational Visitor } \\
Spending \\
\hline Recreation Site & $\begin{array}{c}\text { Industry } \\
\text { Output } \\
\text { Type }\end{array}$ & $\begin{array}{c}\text { Value Added } \\
(\$)\end{array}$ & $\begin{array}{c}\text { Labor Income } \\
(\$)\end{array}$ & $\begin{array}{c}\text { Employment } \\
(\text { Jobs })\end{array}$ \\
\hline Reservoir & $11,561,386$ & $6,580,767$ & $4,185,320$ & 155 \\
River & $16,741,385$ & $9,650,026$ & $6,072,109$ & 201 \\
Total & $28,302,771$ & $16,230,793$ & $10,257,429$ & 356 \\
\hline \hline
\end{tabular}

comparison, Poisson models with these corrections are included in the last two columns. The Negative Binomial model is preferred because the over-dispersion parameter of $\alpha_{0}$ is statistically significant and the Akaike information criteria (AIC) are smaller.

The coefficient for travel cost is statistically significant and negative, indicating a downward sloping demand curve. We find that females visit the area less often than males (Column 1, Row 4). Visitors who engage in fishing activities, either from a boat or onshore, visit the area more frequently than visitors engaged in other recreation activities. Travel cost to an alternative recreation site identified by the respondent, household income, and the age of respondents did not significantly affect the demand (Column 1).

Based on the coefficient of the travel cost variable in Column 1, we derive the consumer surplus per trip using Equation (2). The mean consumer surplus per trip per visitor-group is about $\$ 17.14$, with the 95 percent confidence interval between $\$ 10.03$ and $\$ 36.50$ (Table 8, Column 1, Row 1). Given that the average visitor-group size in our sample is two adults, the consumer surplus per person per trip is about $\$ 8.57$ on average.

Our estimates are consistent with previous studies about freshwater-based recreation in Florida. For example, Shrestha et al. $(2002,2007)$ found that the benefit of recreating in the springs in the Ocala National Forest, which is adjacent to the present study area, was $\$ 9.27$ per person per trip in current dollars adjusted for inflation using the consumer price index (U.S. Bureau of Labor Statistics 2018). Earlier studies by Bell (1987) and Bell et al. $(1995,1998)$ estimated that freshwater-based recreation in Florida lakes offers visitors $\$ 3.30$ to $\$ 3.68$ in consumer surplus per person per day (trip), or $\$ 5.68$ to $\$ 6.06$ in current dollars.

Using the predicted number of trips from the model reported in Column 1 of Table 8, we derive that the annual consumer surplus to be $\$ 111.82$ per visitor-group per year (Table 8, Column 3). Given that the predicted numbers of trips for visitors engaged in fishing activities and other activities are 8.91 and 4.08 per year, respectively, the annual consumer surplus for visitors engaged in fishing activities and other activities are about $\$ 152.79$ and $\$ 69.98$ per visitor-group, respectively. Using the vehicle counts as reported in Table 2, we derive the total economic benefits or total annual consumer surplus from visitor groups at the reservoir sites and river sites as $\$ 2.23$ million and $\$ 3.97$ million, respectively.

(c)Southern Regional Science Association 2019. 
Table 7: Travel Cost Estimation

\begin{tabular}{lcccc}
\hline \hline & Negative Binomial & \multicolumn{2}{c}{ Poisson } \\
\hline Variables & $(1)$ & $(2)$ & $(3)$ & $(4)$ \\
\hline Travel cost $(\$ 100)$ & $-6.298^{* * *}$ & $-7.533^{* * *}$ & $-1.164^{* * *}$ & $-1.188^{* * *}$ \\
& $(1.906)$ & $(2.121)$ & $(0.245)$ & $(0.257)$ \\
Travel cost to an alternative location & 0.057 & & $0.071^{* * *}$ & \\
& $(0.054)$ & & $(0.024)$ & \\
Household income $(\$ 1000)$ & 0.000 & 0.001 & -0.000 & -0.000 \\
& $(0.001)$ & $(0.001)$ & $(0.000)$ & $(0.000)$ \\
Female (if respondent is female) & $-0.884^{*}$ & $-0.753^{*}$ & -0.210 & -0.160 \\
& $(0.462)$ & $(0.436)$ & $(0.185)$ & $(0.189)$ \\
Age & -0.009 & -0.009 & 0.002 & 0.003 \\
Fishing (if respondent is fishing) & $(0.009)$ & $(0.009)$ & $(0.004)$ & $(0.004)$ \\
& $1.661^{*}$ & $1.440^{* *}$ & $0.585^{* * *}$ & $0.616^{* * *}$ \\
Non-motorized boating (if respondent & $(0.851)$ & $(0.612)$ & $(0.202)$ & $(0.205)$ \\
is kayaking or canoeing) & -14.518 & -15.369 & $-0.663^{* * *}$ & $-0.640^{* * *}$ \\
$\alpha_{0}$ & $(643.419)$ & $(848.712)$ & $(0.248)$ & $(0.242)$ \\
& $2.492^{* * *}$ & $2.501^{* * *}$ & & \\
Constant & $(0.057)$ & $(0.057)$ & & \\
& $2.594^{* *}$ & $3.031^{* * *}$ & $3.062^{* * *}$ & $3.146^{* * *}$ \\
N & $(1.213)$ & $(0.935)$ & $(0.366)$ & $(0.379)$ \\
\hline \hline
\end{tabular}

Standard errors in parentheses. ${ }^{* * *} \mathrm{p}<0.01,{ }^{* *} \mathrm{p}<0.05,{ }^{*} \mathrm{p}<0.1$.

Note: The total number of observations was reduced from 681 to 490 after removing observations with missing demographics and those who live 600 or more miles away from the recreation site.

\subsection{Potential Impacts of Dam Breaching}

In the second-round of the survey administered in 2017, we asked the respondents how their recreation visits to the area would change if the dam were breached based on a five-point Likert scale, where 1 is 'decrease greatly' and 5 is 'increase greatly." Table 9 illustrates the percentage of responses for each category after adjusting for avidity. We found that 20.9 percent of the sample indicated that they would reduce their visits greatly to the area if the dam were breached, 13.6 percent indicated their visits would remain the same, 14.9 percent indicated they would increase their visits, and 41.9 percent indicated they were not sure about future visits if the dam were breached (Table 9).

With this information, we expect that there would be a loss of economic benefits and regional value-added economic contributions due to reduced visitation by people engaged in fishing activities, particularly at the reservoir sites. However, the total economic contribu-

\footnotetext{
${ }^{4}$ Ideally, we would like to solicit the change in the number of trips under the scenario of restoring the river. However, in the survey pre-test, most respondents were unable to estimate the exact change or percent change in future trip frequency.
}

(c)Southern Regional Science Association 2019. 
Table 8: Estimated Recreation Benefits (Consumer Surplus)

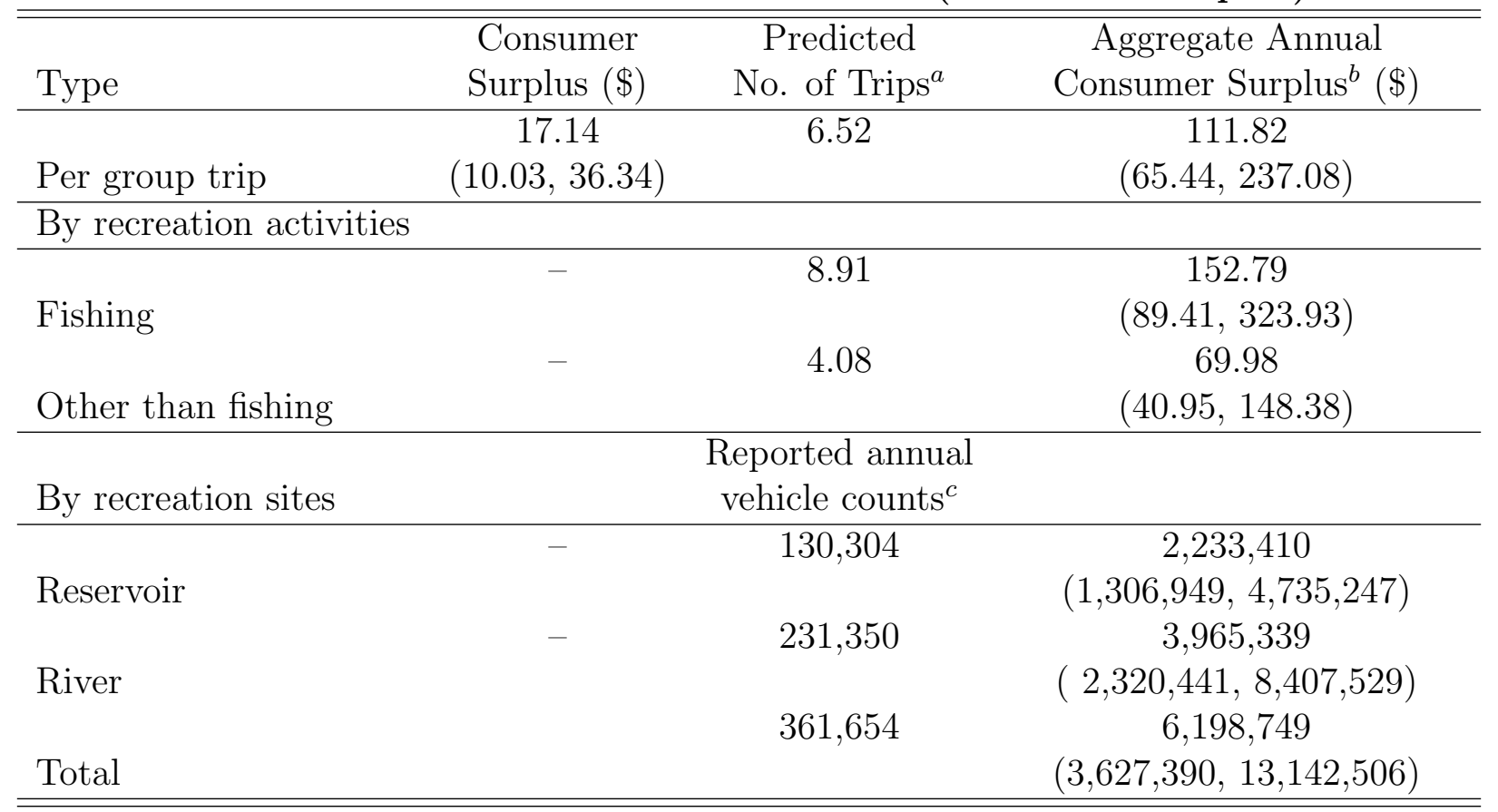

95 percent confidence interval in parentheses.

${ }^{\text {a }}$ The predicted number of trips is derived from $E\left(T_{i} X\right)=\hat{\lambda_{t}}+1+\hat{\alpha_{0}}$ using the estimates in Column 1 of Table 7 .

${ }^{\mathrm{b}}$ Aggregate annual consumer surplus equals the consumer surplus per group per trip multiplied by the predicted number of trips.

${ }^{\mathrm{c}}$ Reflecting the number of vehicle counts reported in column 1 of Table 2.

tions and economic benefits from recreation offered by the river sites exceed those from the reservoir alone. The total economic benefits from the river sites under the current condition are $\$ 3.96$ million, which is 23 percent greater than the recreation benefits from the reservoir. The total economic contributions in terms of value-added from the river sites are $\$ 9.65$ million, which is 53 percent greater than the economic contributions from the reservoir.

Additionally, a significant proportion of the respondents were uncertain about their future visits to the area following dam breaching. Around 41.9 percent of the respondents in the whole sample and 56.3 percent of the respondents at the river sites indicated they were unsure about their future visits to the area, which may be due to lack of information on recreational opportunities after dam breaching.

The potential economic loss may be further limited since there are many substitute freshwater-based recreation sites. In the event that the Ocklawaha River and Rodman Reservoir became unavailable, respondents identified other lakes and rivers nearby as their alternative choices. Among 93 respondents who provided alternative locations, the top alternatives were the St. Johns River (46.2 percent), Santa Fe Lake (16.1 percent), Lake Lochloosa (11.8 percent), Lake George (10.8 percent), and Orange Lake (8.6 percent). Thus, economic activities may shift to other lakes and rivers in the same region.

(C)Southern Regional Science Association 2019. 
Table 9: Responses about Changes in Visits if Dam were Breached Adjusted for Avidity Bias

\begin{tabular}{lccc}
\hline \hline $\begin{array}{l}\text { Percent of respondents reporting a change in } \\
\text { visitation to the area }(\$)\end{array}$ & $\begin{array}{c}\text { Whole Sample } \\
(\mathrm{N}=245)\end{array}$ & $\begin{array}{c}\text { River }^{a} \\
(\mathrm{~N}=137)\end{array}$ & $\begin{array}{c}\text { Reservoir }^{b} \\
(\mathrm{~N}=108)\end{array}$ \\
\hline Visit would decrease greatly or never come back & 20.9 & 8.5 & 44 \\
Visit would decrease & 8.5 & 3.9 & 17 \\
Visit would remain the same & 13.6 & 12.3 & 16.1 \\
Visit would increase & 5.3 & 5.9 & 4.2 \\
Visit would increase greatly & 9.6 & 13.2 & 3.1 \\
Not sure & 41.9 & 56.3 & 15.5 \\
\hline \hline
\end{tabular}

${ }^{a}$ Interview locations along the Ocklawaha River including Eureka West, Ray's Wayside Park, and Silver Spring State Park.

${ }^{\mathrm{b}}$ Interview locations of Kirkpatrick Dam and Recreation Areas and Kenwood Landing.

Furthermore, around 19.1 percent of the respondents at the river sites and 7.3 percent at the reservoir sites indicated that their visits to the area will greatly increase. Thus, potentially, their increased visitation would offset some of the loss by visitors who would reduce their visits. For example, during the drawdown, the state of the Ocklawaha River and recreational opportunities along the river are expected to closely resemble the situation after dam breaching. We found that the proportion of respondents engaged in non-motorized boating activities significantly increased during the drawdown period in the first round of surveys in 2016, and we found that the trip expenditures of visitors engaged in non-motorized boating along the river and coming from more than 50 miles away was similar to local motorized boaters at the reservoir. Thus, breaching the dam and restoring the river flow may also bring additional recreational demand from those who do not currently visit this region as frequently as they would otherwise. We only interviewed current visitors about their intention to return after dam breaching and potentially new demand may be generated from new visitors who do not visit this area under the current condition. An off-site survey on all Florida residents is needed in order to assess the potential of attracting new visitors to a restored river.

\section{CONCLUSION}

This study examined the economic contributions and total economic benefits of recreation provided by the Ocklawaha River and Rodman Reservoir. The analysis of visitors' expenditures showed that activities on the natural stretches of the Ocklawaha River result in greater contributions to the regional economy compared to recreation on the Rodman Reservoir sites. We find that both fishing and non-fishing opportunities are important attractions for visitors to the area and provide economic benefits, though visitors engaging in fishing activities had higher visit frequency.

Unlike previous studies on dam removal in other parts of the U.S. that reported significant increases in recreation as a result of river restoration, this study presents a case when the 
river restoration has a more complex effect on recreation, increasing some types of activities (such as canoeing and kayaking), but potentially reducing other types (such as fishing). Currently, the reservoir is supporting 155 jobs and generating $\$ 4$ million in labor income annually, while recreation along the river supports 201 jobs and $\$ 6$ million in labor income annually. Recreation at the river sites generates greater economic contributions and benefits than they do at the reservoir sites due to the differences in their sizes, as the river covers a larger area than the reservoir. Survey respondents at the reservoir sites were more certain about their intended visits following the restoration, with 61 percent indicating a reduction in their visits to the sites. The impacts of breaching the dam and restoring the river would depend on the extent to which local businesses serving the reservoir sites are able to adapt to changes in recreation preferences. Specifically, with a restored river, recreation activities such as non-motorized boating may increase. Visitors may also switch from fishing on a reservoir to fishing along the river, or to fishing in other nearby freshwater lakes.

To minimize the potential negative impacts of breaching the Kirkpatrick Dam on fishing activities in the region, the Ocklawaha restoration plans should focus on expanding and enhancing onshore fishing opportunities along the restored Ocklawaha River and at other sites in the region to ensure that fishing activities continue to serve as a main attraction to the region as a whole. Additionally, with fishing activities being a draw for low-income local residents, adding fishing decks with access roads along the river could address potential distributional consequences.

Furthermore, our analysis indicated that non-local visitors engaged in river-based recreation activities had higher trip expenditures. While a restored river could potentially attract more non-local visitors, 56 percent of the survey respondents at the river sites were less certain about their intended visits after restoration. In order to attract more visitors to a restored river, a restoration project would need to enhance river-based recreation opportunities and better inform the public about the restoration outcome and timeline. An off-site survey of the public would be able to assess the potential of attracting new visitors under the scenario of breaching the dam and restoring the river.

Overall, given the current trends in dam construction in developing countries and dam removal in the U.S., the assessment of the impacts of dam construction and removal remains an important topic, with more economic studies on this topic needed to inform stakeholders of potential tradeoffs.

\section{REFERENCES}

American Society of Civil Engineers. (2017) 2017 Report Card for America's Infrastructure: Dams. Available online in July 2019 at https://www.infrastructurereportcard.org/wpcontent/uploads/2017/01/Dams-Final.pdf.

Bell, Frederick W. (1987) "The Economic Impact and Valuation of the Recreational and Commercial Fishing Industries of Lake Okeechobee, FL," Final Report to the Florida Game and Freshwater Fish Commission and Florida Department of Environmental Protection: Tallahassee, FL.

Bell, Frederick W, Harry McGinnis, Christine Story, and Paul Rose. (1995) "The Economic

(C)Southern Regional Science Association 2019. 
Value of Lake Jackson," A.L. Burruss Institute of Public Service, Kennesaw State University: Kennesaw, GA.

Bell, Frederick W, Harry McGinnis, Christine Story, and Paul Rose. (1998) "The Economic Value of Lake Tarpon, Florida, and the Impact of Aquatic Weeds," A.L. Burruss Institute of Public Service, Kennesaw State University: Kennesaw, GA.

Bellmore, J. Ryan, Katherine Vittum, Jeffrey J Duda, and Samantha L Greene. (2016) "USGS Dam Removal Science Database," U.S. Geological Survey: Reston, VA.

Bin, Okmyung, Craig E Landry, Christopher L Ellis, and Hans Vogelsong. (2005) "Some Consumer Surplus Estimates for North Carolina Beaches," Marine Resource Economics, 20(2), 145-161.

Bockstael, Nancy E and Ivar E Strand. (1987) "The Effect of Common Sources of Regression Error on Benefit Estimates," Land Economics, 63(1), 11-20.

Bohlen, Curtis and Lynne Y Lewis. (2009) "Examining the Economic Impacts of Hydropower Dams on Property Values using GIS," Journal of Environmental Management, 90, S258S269.

Brown, Phillip H, Desiree Tullos, Bryan Tilt, Darrin Magee, and Aaron T Wolf. (2009) "Modeling the Costs and Benefits of Dam Construction from a Multidisciplinary Perspective," Journal of Environmental Management, 90, S303-S311.

Dolnicar, Sara, Geoffrey I Crouch, and Patrick Long. (2010) "Environmental-Friendly Tourists: What Do We Really Know about Them?," Journal of Sustainable Tourism, 16(2), 197-210.

Englin, Jeffrey and J Scott Shonkwiler. (1995) "Estimating Social Welfare Using Count Data Models: An Application to Long-Run Recreation Demand under Conditions of Endogenous Stratification and Truncation," The Review of Economics and Statistics, 77(1), 104-112.

Florida Department of Environmental Protection. (1995) "A Socio-Economic Study of the Rodman Reservoir," FDEP: Tallahassee, FL.

Florida Department of Environmental Protection. (2001) "Basin Status Report: Ocklawaha," FDEP: Tallahassee, FL.

Florida Department of Environmental Protection. (2015) "Frequently Asked Questions Rodman Reservoir Drawdown October 2015 through February 2016," FDEP: Tallahassee, FL.

Florida Fish and Wildlife Conservation Commission. (2018) "Rodman Reservoir," FFWCC: Tallahassee, FL.

Gilman, Sarah. (2016) This Will Be the Biggest Dam-Removal Project in History. Available online in July 2019 at http:/ news.nationalgeographic.com/2016/04/160411-klamathglen-canyon-dam-removal-video-anniversary/.

Governor Rick Scott. (2016) "Florida's Award-Winning State Parks and Trails Continue Record-Breaking Success," State of Florida Government: Tallahassee, FL. Available online in July 2019 at http://www.flgov.com/floridas-award-winning-state-parks-and-trailscontinue-record-breaking-success-2/.

Graf, William L.. (1999) "Dam Nation: A Geographic Census of American Dams and Their Large-Scale Hydrologic Impacts," Water Resources Research, 35(4), 1305-1311.

Haab, Timothy C and Kenneth E McConnell. (2002) "Single Site Demand Estimation," In Haab, T.C. and K.E. McConnell, eds., Valuing Environmental and Natural Resources: The Econometrics of Non-Market Valuation. Edward Elgar: Cheltenham, UK, pp. 151-189.

Ho, Michelle, Upamanu Lall, Maura Allaire, Naresh Devineni, Hyun H Kwon, Indrani Pal,

(C) Southern Regional Science Association 2019. 
David Raff, and David Wegner. (2017) "The Future Role of Dams in the United States of America," Water Resources Research, 53, 982-998.

ICF Consulting. (2005) "A Summary of Existing Research on Low-Head Dam Removal Projects," Report to American Association of State Highway and Transportation Officials (AASHTO), ICF Consulting: Lexington, MA.

IMPLAN Group, LLC. (2004) "IMPLAN Software for Impact Analysis and Social Accounting (Version 3.0)," IMPLAN: Huntersville, NC.

Internal Revenue Service. (2015) "Standard Mileage Rate (2015)," Internal Revenue Service: Washington, DC. Available online in July 2019 at https://www.irs.gov/taxprofessionals/standard-mileage-rates.

Kareiva, Peter. (2012) "Dam Choices: Analysis for Multiple Needs," Proceedings of the National Academy of Sciences, 109(15), 5553-5554.

Kibler, Kelly M, Desiree D Tullos, and G. Mathias Kondolf. (2011) "Learning from Dam Removal Monitoring: Challenges to Selecting Experimental Design and Establishing Significance of Outcomes," River Research and Applications, 27, 967-975.

Kotchen, Matthew J, Michael R Moore, Frank Lupi, and Edward S Rutherford. (2006) "Environmental Constraints on Hydropower: An Ex Post Benefit-Cost Analysis of Dam Relicensing in Michigan," Land Economics, 82(3), 384-403.

Krinsky, Itzhak and A. Leslie Robb. (1986) "On Approximating the Statistical Properties of Elasticities," The Review of Economics and Statistics, 68(4), 715-719.

Landry, Craig E, R Lewis, Alyson, Haiyong Liu, and Hans Vogelsong. (2016) "Addressing Onsite Sampling in Analysis of Recreation Demand: Economic Value and Impact of Visitation to Cape Hatteras National Seashore," Marine Resource Economics, 31(3), 301-322.

Lewis, Lynne Y, Curtis Bohlen, and Sarah Wilson. (2008) "Dams, Dam Removal, and River Restoration: A Hedonic Property Value Analysis," Contemporary Economic Policy, 26(2), $175-186$.

Lewis, Roy R.. (2015) "Management and Restoration of the Fish Populations of Silver Springs and the Middle and Lower Ocklawaha River, Florida, USA.," Report to Putnam County Environmental Council: Palatka, FL.

Loomis, John. (1996) "Measuring the Economic Benefits of Removing Dams and Restoring the Elwha River: Results of a Contingent Valuation Survey," Water Resources Research, $32(2), 441-447$.

Loomis, John. (2002) "Quantifying Recreation Use Values from Removing Dams and Restoring Free-Flowing Rivers: A Contingent Behavior Travel Cost Demand Model for the Lower Snake River," Water Resources Research, 38(6), 1066-1073.

Loomis, John, Paula Kent, Liz Strange, Kurt Fausch, and Alan Covich. (2000) "Measuring the Total Economic Value of Restoring Ecosystem Services in an Impaired River Basin: Results from a Contingent Valuation Survey," Ecological Economics, 33(1), 103-117.

Loomis, John, Cindy F Sorg, and Dennis Donnelly. (1986) "Economic Losses to Recreational Fisheries due to Small-Head Hydro-Power Development: A Case Study of Henrys Fork in Idaho," Journal of Environmental Management, 22(1), 85-94.

McKean, John, Donn Johnson, and R. Garth Taylor. (2010) "Willingness-to-Pay for Steelhead Trout Fishing: Implications of Two-step Consumer Decisions with Short-Run Endowments," Water Resources Research, 46, W09523.

McKean, John, Donn Johnson, and R. Garth Taylor. (2012) "Three Approaches to Time

(C)Southern Regional Science Association 2019. 
Valuation in Recreation Demand: A Study of the Snake River Recreation Area in Eastern Washington," Journal of Environmental Management, 112, 321-329.

McKean, John, Donn Johnson, R. Garth Taylor, and Richard L Johnson. (2005) "Willingness to Pay for Non Angler Recreation at the Lower Snake River Reservoirs," Journal of Leisure Research, 37(2), 178-194.

Miller, Ronald E and Peter D Blair. (2009) Input-Output Analysis: Foundations and Extensions. Cambridge University Press.

Nijhuis, Michelle. (2015) "Movement to Take Down Thousands of Dams Goes Mainstream," National Geographic: Available online in July 2019 at http://news.nationalgeographic.com/news/2015/01/150127-white-clay-creek-damremoval-river-water-environment/.

Nilsson, Christer, Catherine A Reidy, Mats Dynesius, and Carmen Revenga. (2005) "Fragmentation and Flow Regulation of the World's Large River Systems," Science, 308(5720), 405-408.

Noll, Steven and David Tegeder. (2015) Ditch of Dreams: The Cross Florida Barge Canal and the Struggle for Florida's Future. University of Florida Press.

Null, Sarah E, Josue Medellin-Azuara, Alvar Escriva-Bou, Michelle Lent, and Jay R Lund. (2014) "Optimizing the Dammed: Water Supply Losses and Fish Habitat Gains from Dam Removal in California," Journal of Environmental Management, 136, 121-131.

Parsons, George R. (2003) "The Travel Cost Mode," In Bole, K.J. and T.C. Brown, eds., A Primer on Nonmarket Valuation. Springer: Dordrecht, Netherlands, pp. 269-329.

Provencher, Bill, Helen Sarakonis, and Tanya Meyer. (2008) "Does Small Dam Removal Affect Local Property Values? An Empirical Analysis," Contemporary Economic Policy, 26(2), 187-197.

Robbins, Jesse L and Lynne Y Lewis. (2008) "Demolish It and They Will Come: Estimating the Economic Impacts of Restoring a Recreational Fishery," Journal of the American Water Resources Association (JAWRA), 44(6), 1488-1499.

Shaw, Daigee. (1988) "On-Site Samples' Regression: Problems of Non-Negative Integers, Truncation, and Endogenous Stratification," Journal of Econometrics, 37(2), 211-223.

Shi, Wei and Ju-Chin Huang. (2018) "Correcting On-Site Sampling Bias: A New Method with Application to Recreation Demand Analysis," Land Economics, 94(3), 459-474.

Shrestha, Ram K, Janaki R.R Alavalapati, Taylor V Stein, Douglas R Carter, and Christine B Denny. (2002) "Visitor Preferences and Values for Water-Based Recreation: A Case Study of the Ocala National Forest," Journal of Agricultural and Applied Economics, 34(3), 547559.

Shrestha, Ram K, Taylor V Stein, and Julie Clark. (2007) "Valuing Nature-Based Recreation in Public Natural Areas of the Apalachicola River Region, Florida," Journal of Environmental Management, 85(4), 977-987.

Shuman, John R. (1995) "Environmental Considerations for Assessing Dam Removal Alternatives for River Restoration," Regulated Rivers: Research and Management, 11(3-4), 249-261.

Smith, Mark G. (2006) "Dam Removal: A Taxonomy with Implications for Economic Analysis," Journal of Contemporary Water Research and Education, 134, 34-38.

Stanley, Emily H and Marin W Doyle. (2003) "Trading Off: The Ecological Effects of Dam Removal," Frontiers in Ecology and the Environment, 1, 15-22.

(C)Southern Regional Science Association 2019. 
Thomson, Cynthia J. (1991) "Effects of the Avidity Bias on Survey Estimates of Fishing Effort and Economic Value," American Fisheries Society Symposium, 12, 356-366.

Tullos, Desiree, Byran Tilt, and Catherin R Lierman. (2009) "Introduction to the Special Issue: Understanding and Linking the Biophysical, Socioeconomic, and Geopolitical Effects of Dams," Journal of Environmental Management, 90, S203-S207.

U.S. Army Corps of Engineers. (2016) "CorpsMap. National Inventory of Dams," USACE: Washington, DC.

U.S. Department of Agriculture Forest Service. (2001) "Draft Environmental Impact Statement for the Ocklawaha River Restoration Project," USDA-FS: Atlanta, GA.

U.S. Environmental Protection Agency. (2016) "Frequently Asked Questions on Removal of Obsolete Dams," USEPA: Washington, DC. Available online in July 2019 at https://www.epa.gov/sites/production/files/201612/documents/2016_december_2_clean_final_dam_removal_faqs_0.pdf.

U.S. Fish and Wildlife Service. (2016) "Quick Facts from the 2016 National Survey of Fishing, Hunting, and Wildlife-Associated Recreation," USFWS: Washington, DC. Available online in July 2019 at https://www.census.gov/library/visualizations/2016/demo/fhw-16nat.html.

Visit Florida. (2017) "Research: Top Origin States by Percentage of Domestic Visitors in 2017," Visit Florida: Tallahassee, FL. Available online in July 2019 at https://www.visitflorida.org/resources/research/.

Whitehead, John C, Timothy C Haab, and Ju-Chin Huang. (2000) "Measuring Recreation Benefits of Quality Improvements with Revealed and Stated Behavior Data," Resource and Energy Economics, 22(4), 339-354.

Whitelaw, Ed and Ed MacMullan. (2002) "A Framework for Estimating the Costs and Benefits of Dam Removal," BioScience, 52(8), 724-730.

World Commission on Dams. (2000) Dams and Development: A New Framework for Decisions-Making. Earthscan Publications.

(c)Southern Regional Science Association 2019. 